EUROPEAN JOURNAL OF CURRENT LEGAL ISSUES, VOL 21, NO 1 (2015)

\title{
The UK Supreme Court - is there anything left to think about?
}

Penny Darbyshire [1]

Cite as Darbyshire, P., "The UK Supreme Court - is there anything left to think about?", (2015) 21(1) European Journal of Current Legal Issues.

\section{ABSTRACT}

Alan Paterson's latest masterwork has left no stone unturned. [2] It is executed with the same breadth and depth but with even more attention to detail than his Law Lords book. [3] It will serve as a uniquely informative and thought-provoking reference work for generations of scholars. Very few academics have the guts and the energy to conduct empirical research, especially with elites. No-one has analysed the top court with Paterson's intelligence and insight. His painstaking work is humbling to the rest of us. This article therefore modestly offers a few reflections to mull over and points to watch in future. [4] Every year, I take my class of American law students in to observe the Court and meet a different Justice and a judicial assistant, and to observe proceedings. I ask them to think about the following points and compare the UKSC in these respects with the US Supreme Court.

\section{THE CONSTITUTIONAL POSITION OF THE UK'S TOP COURT}

Unlike other top courts, the UK's Supreme Court does not review the constitutionality of legislation, partly because the UK is one of only four countries in the developed world without a written constitution so there is no single codified instrument against which to measure law's constitutionality and indeed no concept of "unconstitutional", in the UK. The other reason is the supremacy of Parliament. This is the by-now unspoken bedrock principle of the unwritten constitution. It is so taken for granted in the UK since its establishment after the Glorious Revolution of 1688, that the 2003 consultation paper heralding the establishment of the UKSC did not even raise the possibility of giving the top court the power to judicially review the constitutionality of the law [5] and it was left to a handful of academics and Baroness Hale to canvass this and other more imaginative options. [6] Lord Neuberger's mere suggestion that the UKSC might one day have a Marbury $v$ Madison moment and give itself reviewing power was instantly slapped down by former top law lord, Lord Bingham and the first UKSC President, Lord Phillips. [7] Consider

these two points, however. First, while Americans take it for granted that their top court can judicially review legislation iust as stronglv as we take for granted that our court cannot. what Americans do not 
realise until they reach law school (and they greet this news with incredulity), is that the US Supreme Court was not given the judicial review function by the US Constitution. The Court gave itself this power, in the same way that the law lords announced in 1966 that they were giving themselves the power to depart from their own precedents. Obviously, this is a pale analogy but by doing so the law lords did amend the unwritten UK constitution. The second point is this. Parliamentary supremacy conflicts with the rule of law, as explained in Lord Bingham's parting gift to the world, his brilliant book, The Rule of Law. [8] He got the idea from eminent constitutionalists such as Sir Francis Jacobs and Vernon Bogdanor. Now, we could have bumbled along happily with this conflict, because, practically, the House of Lords (upper chamber of Parliament) could stop the House of Commons passing laws which breached the rule of law but, thanks to the Parliament Acts, "our constitutional settlement has become unbalanced", so the Commons can now ignore the Lords and enact legislation without them, and, as Bingham pointed out, the Commons has contemplated some fairly scary breaches of the rule of law in recent years, such as a clause precluding legal challenge through the courts, in a 2004 Act. The conflict, then:

"... is not a problem which will go away if we ignore it, but it may perhaps give rise, as Professor Bogdanor fears, to wholly undesirable conflict between Parliament and the judges." [9]

Bingham contemplates that the British people might one day decide to substitute constitutional sovereignty for Parliamentary sovereignty. This is not far-fetched. The Conservative party keep suggesting a British Bill of Rights to replace the Human Rights Act 1998. (Incidentally, with infallible logic, Lord Bingham pointed out that the arguments that parliamentary sovereignty had been undermined by the European

Communities Act 1972, the Human Rights Act 1998 and the 1998 devolution legislation were red herrings, since Parliament could revoke all of these statutes). [10] Consider this: my intelligent American students and I decided the UKSC is in a better position that the US Supreme Court to test the constitutionality of primary legislation against a written constitution or Bill of Rights, in a dispassionate and objective manner, because the UK Justices are not party political at all, unlike their US counterparts, who are party political nominees.

\section{THE WAY THEY WORK - PANEL SIZE}

The US Supreme Court sits en banc as a court of nine. The UK top court has traditionally sat in fives of the twelve available. [11] Before they transformed into a Supreme Court, the law lords were very familiar with

and sympathetic to the argument that one panel of five could reach a different decision from a different five and this point is so well-accepted that it was even mentioned by a PA [12] to one of the Justices while she was showing my students round in 2014. Therefore, to add legitimacy to their decisions and deflect 


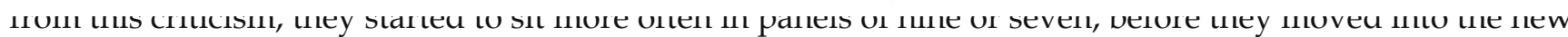
court in 2009. At the first anniversary closed seminar, in 2010, some practitioners and I asked the Justices how they decided which cases merited a large panel of seven or nine. We were swiftly told of the established criteria which, until then, had not been in the public domain. We asked that, for the sake of transparency, these should be published on the Court's website.

- If the Court is being asked to depart, or may decide to depart from a previous decision.

- A case of high constitutional importance.

- A case of great public importance.

- A case where a conflict between decisions in the House of Lords, Judicial Committee of the Privy Council and/or the Supreme Court has to be reconciled.

- A case raising an important point in relation to the European Convention on Human Rights. [13]

If, however, we accept the argument that two separate groups of five may differ in their treatment of any case, then it follows that they should sit in sevens or nines as often as possible, yet this argument seems to have got lost very recently. Statistics presented to those of us attending the UKSC's closed fifth anniversary seminar in October 2014 showed that big panels have gone out of fashion. While there were no fewer than 27 in April 2010-March 2011, this declined to 20 the next year, 10 the following year and only six in April 2013 to March 2014. This table did not appear in the 2014 UKSC annual report and no explanation is offered. [14] In February 2015, I asked two Justices why there were fewer big panels and what they thought. One said:

"I think one of the reasons is the sheer volume of work [15] ... I'm not sure that the bullet points are any longer entirely accurate ... there are examples of our considering departing from previous decisions without a large panel. I'm working on one at the moment, which is to do with the housing (homeless persons) legislation. We're thinking of overturning a 1980s decision ... I was not on the PTA panel, though they sent it to a panel of five. I would favour having more than five when we're asked to depart from our own precedents ... because it's a very important thing ... [He described another current, similar case]... there's another circumstance where we do it and that's where we've run into trouble with a panel of five. There's a case at the moment called Zurich [16] ... It was initially heard by a panel of five. Having heard it, there was sufficiently strong disagreement that it was thought right to re-hear it in front of a panel of seven. The same thing happened in ... a POCA [Proceeds of Crime Act] case. [17] The seven [who heard it] had difficulty coming to a majority decision. It was then reheard in front of nine."

The second Justice also mentioned these cases, in the context of case management:

"I think it's OK ... so long as we do it verv rarely but it isn't verv satisfactory if vou're the sixth 
or seventh or eighth Justice who didn't sit the first time round, whereas the others have heard the whole of the argument already. That's quite tricky ... in a perfect world, for instance if the Scots had gone independent ... we would probably reduce the whole court to nine and then always sit as the whole court."

This topic leads neatly into the next one, because a panel of nine may find it even more difficult than a panel of five to produce a single acceptable majority judgment.

\section{MULTIPLE JUDGMENTS}

My view on this is very simple [18] and was formed when I was a student but strengthened by watching numerous constitutions of the Court of Appeal at work, deliberating and forming their judgments. [19] The UKSC is funded by taxpayers' money. Its job is to determine points of law of general public importance, partly for the parties but mainly to clarify the law for the public. It is a common law court so it makes law. The Court's case law is just as important as the law made by Parliament. It follows logically, then, that there should be a single, clear judgment where possible. This should be the default position. Additional judgments should not be handed down unless they add useful reasoning or information. Multiple conflicting judgments where there is no clear ratio decidendi are downright irresponsible. Of course I am familiar with all of the arguments that multiple judgments enrich the law, that the common law is a maze and not a motorway and that combined judgments are "a bland amalgam", because I've been reading these arguments since I was a student. Nevertheless, consider this:

- The public, who pay for the court, have a legitimate expectation that the Court will do its job of clarifying the important points of law which affect them.

- Naturally, "points of law of general public importance" all affect large groups and sometimes the decisions have the potential to affect all citizens or all taxpayers or all residents and so on.

- The public are bound by the law. Ignorance of the law is no defence.

- Members of the public cannot be expected to read multiple judgments, nor should they be expected to pay a lawyer to interpret multiple judgments to find out what their rights and obligations are.

- Most people cannot afford a lawyer. There have been massive cutbacks in legal aid since 2012.

- I wonder who does read multiple judgments. I have not noticed that ordinary lawyers or judges of the lower courts (that is, most judges) read multiple judgments, in the cut and thrust of everyday legal practice. [20]

- Most Justices (eight of the current twelve) are from the Court of Appeal of England Wales. In the Criminal Division they are obliged by law to hand down a single and composite judgment. The Court's criminal case load far outstrips its civil load, meaning that most Court of Appeal judges, even those with no criminal experience are roped into this work, in addition to all QBD High Court judges, 
that is, most High Court judges. So for all of their years in the HC and CA, most judges of Wales and England spend a significant part of their working days collaborating to share the work of writing a composite judgment, or sharing ideas to form a single judgment which is a hidden composite, so why can they not do the same when they get up to the top court? Curiously, Paterson does not examine this point. He merely mentions the CACD rule in a footnote. [21] A Justice to whom I spoke in October 2014 gave the same response as Justices did to me in 2009 [22] - that the Court of Appeal is intensely collegial, that the larger benches in the top court make it more difficult to form single judgments and practice is different so that the judgment writer is not decided until after the hearing, unlike in the Court of Appeal. Like those I cited in 2009, he also thought there was room for more deliberation, especially pre-deliberation.

- In Wales and England, the major case law developer and precedent producer is the Court of Appeal because most appeal cases stop there. The UKSC hears 60-90 cases per year; the CA determines thousands. Most of these are admittedly not precedents but the precedents are in hundreds, not tens. In most CA precedents, the bench speaks with one voice and they are forced to produce their precedents at enormous pressure under a case load that is barely sustainable. As the top court works at a more leisurely pace, why can they not make more effort to deliberate and circulate their draft judgments and reach a consensus, or more of a consensus, in many more cases?

Since I formed my student hostility to multiple judgments, this turned to rage at the sheer irresponsibility of cases like Majewski [23], in criminal law. The decision (or non-decision) in Majewski was about the effect of intoxication on criminal responsibility. This was and is a hugely important point of law. At the time of the decision, about half of all offences in England and Wales involved an element of intoxication in the facts, yet we were served a decision with multiple, incompatible lines of reasoning so that even the intellectual giants who wrote criminal law textbooks struggled to make sense of it and extrapolate a principle suitable for practical application in all relevant cases where the accused had been intoxicated. It was left to the Court of Appeal to tell us how the unprincipled reasoning in Majewski could be applied on a case by case, crime by crime basis. I am not alone in my irritation. Lord Justice Carnwath famously expressed his exasperation in Doherty v Birmingham City Council [24] at the law lords' decision in Kay: [25]

"Was it necessary for the opinions of the House to have come to us in the form of six substantive speeches, which we have had to subject to laborious comparative analysis to arrive at a conclusion? Could not a single majority speech have provided clear and straightforward guidance, which we could then have applied directly to the case before us?" [26]

He was rapidly supported by his fellows, such as Lord Justice Neuberger, Lady Hale and Lady Justice Arden. [27] Neuberger [28] and Hale are fans of the single majority judgment. Lady Justice Arden is too and called for clearer, shorter judgments. [29] She thought this could be achieved by more internal engagement. 
I said above that the issues discussed here are points to watch so how is the UK Supreme Court doing on this point, especially now that Lord Neuberger is the very President of the Court and Lord Carnwath is one of the Justices? Brice Dickson publishes very useful annual statistics in the New Law Journal. In 2014, he reported on the continued trend towards single judgments, manifest in 46 of the 81 decisions in 2013, 57 per cent. [30] Lord Neuberger continues to emphasise the need for clarity and coherence, for the public good. For instance in August 2014, speaking in Australia, he said:

"A judge's duty to uphold the law carries with it an obligation ... to do her best to ensure that the court ... produces as clear and coherent a judgment or set of judgments as is consistent with each member's opinion." [31]

He continues in all of these speeches, to criticise "vanity judgments". Yet, if you speak to individual Justices now, they are aware that they could do better. When I spoke to individuals in 2009 , they pointed to the nine long judgments in the Jewish Schools case. The Justice to whom I spoke in 2014 pointed to the Nicklinson case, where all nine on that bench felt compelled to give judgments totaling 131 pages, starting with Lord Neuberger's 46 pages. [32] This case was about assisting the suicide of a man paralysed through a stroke so it could affect any resident of the UK yet, to make sense of it, those citizens are entirely dependent on the press summary. (The law lords did not provide this much). The Justice thought that with more deliberation, the judgments could have been whittled down to three lines of reasoning.

Why does the delivery of multiple judgments arise? Is Lady Justice Arden right - lack of internal engagement? Three Justices to whom I spoke in February 2015 were adamant that there was much more internal engagement nowadays. One said "I agree with your thesis that we shouldn't have so many multiple judgments, if we can avoid it. I think you're probably over critical". That reflected all three opinions. He went on, however:

"I agree with you that there are too many concurring judgments. I agree with you that you should only write a concurring judgment if you've got something different to say. I think over the years we've been rather bad at that ... I remember when I was in the Court of Appeal, if you had to pore over some judgment of their lordships trying to work out of the four apparently concurring judgments, who say they agree with each other but on analysis don't agree with each other, that's a great mistake."

This Justice deprecated former members of the Court who could not resist adding in their own "75 paragraphs in every case", as he put it but another explained:

"I think this court is ... collaborative ... We have ... intensive team working ... We've deliberately 
not gone down the juge rapporteur route because it encourages a lack of effort ... instead, everybody prepares the case intensively ... which is a huge strength of the court. You get the benefit of ... different perspectives ... [feeding] into the deliberations. When we have our discussion, the presiding judge will usually ask somebody to write first but it by no means follows that that person's judgment will be the leading judgment ... Others may disagree. Others may pre-empt that judgment by circulating a contrary judgment. Once judgments have been circulated - by anyone who feels moved to write ... others will feed in their input by email exchanges. If they are basically in agreement but have issues, they will raise those issues and the writer will endeavour to take them on board so far as he or she feels that they can. If there's a difference which isn't going to be bridged, then the person that's not happy may obviously write their own judgment. That may attract adherents. So you can have many different drafts of a judgment, where many people have had an input ... You could properly describe it as an iterative process ... You might have 50 emails being circulated. Sometimes there are seven or eight drafts of a judgment so it's very collaborative. We're all too busy just to write for the sake of it so you only write if you've taken on the responsibility for writing the principal judgment in the case, or if you are unable to agree with that and you feel that it's worth writing a different, maybe a concurring judgement, or a dissenting judgment. Dissents are relatively unusual unless there's more than one person ... We do sometimes write composite judgments ... There are quite a lot of joint judgments now and that's a new development in the last few years. If we give a single judgment it will in reality be a collaborative product ... [He was not keen that single judgments should become the norm] ... Sometimes where we're reading ... judgments [from decades earlier] ... where we're having trouble ... it's because it's a single judgment and has not been particularly ... clearly written, and ... you think 'If only Lord Wilberforce had written, you might have a better idea of what this is about' ... The cases that

cause us the most trouble are the ones which take the longest. We've got one where we're delivering judgment in March in a case heard in July of last year, on medical negligence and giving informed consent [33] and we've got one on the legality of the benefits cap which we heard in March last year, [34] where we still haven't issued judgment and that's a reflection of the problems we're having getting the judgment finalised ... [About] the Nicklinson case: I was very dismayed by the fact that there were nine judgments. I was determined to stick out and not write, until [X] wrote a judgment, attributing a view to me which I didn't hold so I had to write a very short judgment but I thought the fact that we wrote nine, indicated how unsuitable the issue was for a judicial decision. I think you could say that was an exceptional case where it was clearly going to go back to Parliament for reconsideration ..."

The other did not agree with any criticism of the Nicklinson case, as voiced by his fellow Justice to me in D.1 - L... nn1 1 
"Some of us took the view that it was really a matter for Parliament but it was necessary to indicate to Parliament what we thought they ought to be doing about it and of course we didn't quite all take the same view about that but that's quite a complicated question. Parliament's still dithering about it. I'm not sure Parliament has even now taken on the kind of case that we were dealing with ... Some of these questions are not solely legal questions ... They're sort of politico-legal questions."

He had a novel suggestion for making sense of the more complex cases with more than one judgment:

" ... a sort of referendaire, or somebody to look at all the judgments and produce a critique of them, to try and identify where they do agree and where they really don't agree and then have a bit of discussion about that. I think that's quite a good idea but we never quite got round to that but one of these days I think we might.

This issue is linked to the next topic.

\section{CASE MANAGEMENT, PRE-DELIBERATION AND ORAL HEARINGS}

The issues of case management, oral hearings and judicial preparation are linked. [35] Oral hearings have been reduced to a day or two and this is seen as a great achievement, compared with four-day sessions reported by Paterson in the 1970s. Indeed, it is heartening to see that, in the Hilary Term (spring) 2015, there are ten one-day hearings, two half-days and three 1.5 day hearings, though there are six two-day

cases and one 2.5 day case. This has to be set against a background where oral hearings in the US Supreme Court are 30 minutes and the Court of Justice of the EU might permit 10 minutes or nothing. There is usually little attempt at case management (in the sense of apportioning the allocated time between the advocates, limiting the authorities, requiring mini-skeleton arguments, listing the issues on which they wish to be addressed, and not addressed, and so on). In the complex cases, Justices will give directions at the permission stage about timetables and documentation. [36] I wondered if better case management and pre-deliberation might reduce the length of oral hearings and might prevent the instance of the parties being recalled after the oral hearing or asked for written submissions on questions that had arisen only during the oral hearing.

The first judge interviewed in 2015 thought supplementary arguments would not be avoided by more predeliberation and case management and were not, in any event, a bad thing:

"It's important to give the right answer, and if the parties haven't identified an important point, 
and it occurs to us, tnen we snouid ralse it ... I fus is not tnat unusual. I nere are a number or cases where it's happened in the last year ... Eastenders [37] ... where a point occurred to me after the hearing had taken place. My colleagues thought there was merit in it so we put it to the parties. They made written submissions and at the end of the day we decided the case on that point. Anson, [38] a point occurred to me when preparing for the hearing. It was there in embryo but it hadn't really been developed. We thought it was quite important so we raised it at an early stage of the hearing and, in the light of counsel's responses, invited written submissions on it, and we're now going to have a further hearing on that ... Bourgass [39] where counsel had spotted a point which had not been argued below but had only been instructed at a very late stage. There was enough of a little hint about it for us to pick it up and run with it. We then asked them to put in written submissions. Cramaso [40], where a point occurred to us at the pre-hearing discussion: we raised it right away at the hearing and they put in written submissions. Osborn [41] where they argued the case on European human rights cases and we decided we were going to decide it on domestic administrative law and we raised that and they put in written submissions afterwards. Zurich [42] where there is a question about whether we should decide the case on a basis that the parties have expressly disavowed. That was also the case in Eastenders. We decided it for the Revenue on a basis that the Revenue disavowed. Hemming [43] a recent case where we raised a point that had occurred to us at the hearing and written submissions are now being put in. Would better prep have precluded this? The problem is, we do look at the case at the PTA stage and we sometimes see points then. Just this morning I have done I have directed that the parties' attention should be

drawn to a couple of cases that they may not be aware of because they're Privy Council cases but sometimes I'm afraid it's only when your mind is intensely focussed - sometimes you wake up in the middle of the night - after you've been working on a case all day and your brain has continued to work away on it. You're just not that intensely engaged before the hearing begins. They're not obvious points because if they were they would already have been raised. The case has already been through the hands of counsel and obviously two levels of courts ... we're here because we're supposed to be good at it. If there are five of us all working intensively, sparks are given off. I don't think you would reduce the incidence of that appreciably by having the sort of juge rapporteur system."

There was no appetite among the three judges to whom I spoke in 2015 for more case management. They said that they could give directions at the permission stage on the hearing length and issues to focus on and "We do get the best of the bar here by and large", said one. Another thought there would be more room for more pre-deliberation, if only they had the time but they were still going much further than the law lords and they all thought I was too harsh: 
"I'heir Lordships, I think they met for about a minute betore they started. Some of them thought it was constitutionally unsound to discuss the cases beforehand."

The Justices are keen to keep their oral hearings, because they enjoy them and consider them to be productive. They enjoy the debates with the advocates and Paterson found that in the UKSC, as with the 1970s law lords, the judges use the time to debate with one another too. Anyone can see this for themselves in open court. I watch the Justices each year. We need to ask, though: is this an appropriate use of time and resources? Is it fair to the parties, including the impoverished Legal Aid Fund, to sponsor debates between the Justices that they could have had in a pre-deliberation hearing, given that they each have the whole argument in writing and the authorities in a bound volume, the Printed Case, a procedure dating back to the 1690s (yes, the seventeenth century). The other difficulty with oral hearings and anyone can see this for themselves - the lawyers start re-introducing the case that they have already introduced in writing. Another problem is, as I said in 2011 and it is still the case, as any court observer can see, there is still far too much recitation of, for instance, legislation, and the Justices are often too polite to stop this in its tracks, though they do give Privy Council advocates short shrift, especially when the issues are trivial, as they often are. There is yet another problem with pre-reading and case management that a Justice pointed out to us in October 2014. The advocates swamp the Court with authorities "sixty, seventy or eighty authorities when only six will be of relevance". The Court of Appeal is continually complaining about this, to no avail. [44]

While all four Justices to whom I spoke in 2014-15 acknowledged that some oral hearings might be shorter and there was too much recitation, which they were too polite to stop, they all valued oral hearings, as an intellectual cauldron. As one said:

"I wouldn't like to go over to an American situation where there isn't any argument. Oral argument does have its effect even in the Supreme Court of the US. I met a judge on the appeal circuits and I said to him, 'how often do you go into court?'. He said about once every six weeks. For the rest of the time, he said, we read the briefs. That would be a very dispiriting way of life I think. I actually think that oral argument is valuable as a method of trying to focus the mind. We quite often change our minds. Even people who have quite firm views quite often change their mind in the light of discussion."

Another drew attention to a transparency bonus that had not occurred to me:

"One of the advantages, I think, is in terms of public accountability. People always ask, how are judges made accountable? We are one of the very few people who actually work in public on screen, in the visible part of our work ... We could be watched from 10.30 to 4 each day for years on end. People can see us doing our job." 
As for my point about their having the whole of the printed case in advance, this Justice added:

"When you say we have the whole argument, the printed case is really a starting point ... What you really want is ... 20 pages ... So you hit the ground running when the hearing begins, develop their most important points and we can indicate to them what we want them to develop. So the oral hearing is important but it could be shorter. As you say, there's too much recitation. We're sometimes too polite to stop people in their tracks. And as you say, we do tend to be swamped with far too many authorities although in fairness the number actually referred to in court is far fewer than what we are given."

To me, this suggests that the Justices might use case management to be more demanding of the expensive and highly skilled lawyers appearing before them to prepare summaries and identify essential precedents. In the Commercial Court, judges routinely demand further material and summaries, even overnight, that can assist judgment-formation, including basic agreed statements and summaries that can be pasted in. Obviously, the judgment task is different but my point is that it is the advocates' job to assist the court and maybe the Justices should be more demanding at the pre-hearing stage to help them prepare more efficiently and thus make more effective use of the oral hearing.

\section{PRIVY COUNCIL CASES}

As I explained in 2011, some of the Justices drew my attention to some cases that appeared to be so trivial that they could be considered to be a waste of public money. The Justices explained that to cut these out would require legislation in each of the jurisdictions sending cases over. The two Justices who expressed an opinion on the JCPC in $2015 \mathrm{did}$ not share these sentiments. One felt it provided a welcome "change of scene" and he drew attention to the importance of some of the commercial cases from, for example, the Cayman Islands, and the decades of Caribbean death penalty cases where the creative rule-making of the JCPC had ensured that virtually all appellants would escape death. The Chief Executive, Jenny Rowe, was swift to point out, in 2015, that the UK's top court is "proud to serve the jurisdictions that use the JCPC and any decision to move away ... is one for the country/government concerned".

\section{FUNCTIONAL INDEPENDENCE}

The Chief Executive, Jenny Rowe, finds that she still has to repeatedly explain (even to Parliamentarians) the basic constitutional setup of the UKSC administration, as a department of state. In the early days, especially 2010, the Court's first full year, the funding stream was extremely problematic. The Court serves the United Kingdom's three jurisdictions, Scotland, Northern Ireland and England and Wales. England and Wales were slow to pay their share of the budget. At the same time, however, The Ministry of Justice had

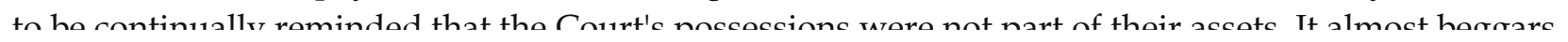




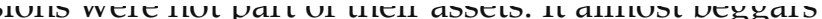
belief that it was mooted in 2010 that the Court's administration should be merged with Her Majesty's Courts and Tribunals Service (which serves Wales and England). The problem arose because the funding setup was not spelled out in statute. It was agreed between ministers in 2006-07 and they had moved on by the time the Court opened in 2009 so the agreement had been forgotten. Happily at last, the Crime and Courts Act 2013 strengthened the Court's structural independence slightly and since 2013, there is a Concordat with the Ministry of Justice, whose purpose is to:

"... highlight the independence of the Court, the process by which the Court secures its resources and to indicate the elements of good practice which inform developing processes and contacts between the Ministry of Justice and the Court". [45]

Nevertheless, the Chief Executive is constantly vigilant to spot external changes that may have an impact. The Coalition Minister of Justice, Chris Grayling, repeatedly uttered the cryptic desire that the Supreme Court should be more supreme. What that meant depended on the outcome of the 2015 general election. Of course, had the Scots voted for devolution in 2014, the Court would have lost one element of its jurisdiction. The issue is still uncertain, pending the outcome of the Smith Commission, which is overseeing further devolution. [46] It will be a long time before lawyers forget Kenny MacAskill's 2011 threat to withdraw funding on the basis that "he who pays the piper ... calls the tune". [47] Changes in legislation and policy may affect the Court, too. For instance, a new route of leapfrog appeals provided for in the Criminal Justice and Courts Act 2015 may affect the UKSC, as The Chief Executive explained, "The potential implications for us is that we will get more cases, and they will be cases where the Justices will not have the benefit of consideration by the Court of Appeal first". She is also aware that there is an increasing number of litigants in person, in the United Kingdom. An LIP has yet to get beyond the application stage but, in readiness, a guide was written in 2014.

\section{TO BE WELCOMED - IMPROVEMENTS IN TRANSPARENCY}

As I said, the Justices and their staff are in continual dialogue with interested academics and the lawyers who often appear before them, through seminars arranged by the Court or the other parties, and because Justices very frequently mix with lawyers and academics when they deliver out-of-court speeches. In its ethos and setup the whole Court is geared up to openness and user-friendliness to an extreme degree. I cannot see how they could do better. My American students are always impressed by the welcome we get. It has an informative and user-friendly website, a live, free TV feed, a Twitter Feed, a YouTube channel, a plethora of information leaflets and informative "toys", as the Justices call them, in the basement. The Court welcomes over three hundred school parties and about 80,000 other visitors each year (and me and my students). Everyone, including the security people, the receptionist, the Executive team, the Justices' PAs and the Justices' Assistants seem to have been trained to be smiley, informative and friendly and they all 
seem happy to provide guided tours and to discuss the court. Like all the judges I have met, there is a complete absence of self-importance and, in the top court, any physical or psychological barrier between them and the outside world. The Justices and staff are ultra-approachable. They are happy to discuss their work and they and their Chief Executive are very open to suggestions, especially to enhance the transparency of the Court.

\section{CONCLUSION}

There is almost nothing new to say but here, I hope to have expressed, in simple terms, some of the changes in the Court since 2011 and to have provided some food for thought. I offer this as a simple article, for future students of the Court. These are some points to watch and consider.

1. The Court does not currently have the power to judicially review statutes of the UK Parliament, because of Parliamentary supremacy. It is not, however, stupidly far-fetched to think that it might

have such power in the future (not least because, as Lord Bingham pointed out, Parliamentary supremacy is incompatible with the rule of law).

2. As the 12 Justices and the President and Deputy leave and are replaced, the top court changes its practices, year on year. It has suddenly stopped its new trend of sitting in larger constitutions more frequently but this may change again.

3. Current Justices interviewed in 2014-15 agree that multiple, superfluous judgments are a nuisance and should be avoided where possible but they pointed to the hard work and great lengths they go to, with massive email exchanges, to narrow down disagreement, or at least to write joint judgments with a fellow Justice.

4. The length of oral hearings has more than halved since the 1970s and the Justices are aware that, through politeness, they are sometimes too tolerant of some unnecessary oral input from advocates. They consider oral argument to be indispensable, however. They see the debate as a vehicle for exploring and refining the issues and, as one Justice said, as this is all in open court and televised, this makes their thinking transparent and makes them publicly accountable in a way that they would not be if they debated behind closed doors, like the US Supreme Court. I have never met a Justice who would advocate adopting the very truncated oral advocacy of the US Supreme Court. Life without the fun of the oral debate would be miserable.

5. While I was surprised that the Justices mentioned a number of cases recently where they halted a case to have it re-heard before a larger bench or where they asked for further argument or supplementary submissions, they did not see that this posed a problem, or could be entirely prevented by more case management or pre-deliberation.

6. As for the Judicial Committee of the Privy Council, The Chief Executive and the Justices have to treat those iurisdictions sending cases to London verv sensitivelv. While some of the cases are trivial and 
appear to be a waste of the Justices' time, its work has been and is of international importance in developing precedent in commercial law, human rights and even in such important areas of domestic law as homicide in Wales and England.

7. The Court is super-transparent and user friendly to the parties, hundreds of schoolchildren, students, tourists and foreign lawyers and judges, internet voyeurs and, of course, researchers like me who have "done the top court to death", over the years. It is probably the world's most open court. I cannot think how it could improve in transparency and if you can think of a way, contact the Chief Executive and she will listen.

\section{[1] Kingston University.}

[2] Final Judgment - the Last Law Lords and the Supreme Court (Hart 2013).

[3] Macmillan 1982.

[4] See my own research and commentary on the top court in chapter 15 of a book on the working lives of all types of judge in Wales and England, Sitting in Judgment - The Working Lives of Judges, "Brenda and the Law Lords transform into the Supremes".

[5] Department for Constitutional Affairs, Constitutional Reform: a Supreme Court for the United Kingdom, CP 11/03, July 2003.

[6] References to books and articles and discussion are in chapter 6 of Darbyshire on the English Legal System (11 $1^{\text {th }}$ edn, Sweet and Maxwell 2014). See especially the special issue of Legal Studies, Vol 24, March 2004.

[7] Sitting in Judgment pp. 401-02.

[8] Allen Lane 2010.

[9] P. 169.

[10] P. 164.

[11] Sitting in Judgment, p. 371-73 and nine references in Final Judgment. 
[12] Yes, a personal assistant, not a judicial assistant.

[13] See now "Rules of the Court", on the website, under "Court Procedures".

[14] But Brice Dickson produces invaluable annual statistical analyses of the top court's work in the New Law Journal.

[15] The Chief Executive says that this is not the reason.

[16] International Energy Group v Zurich Insurance PLC , Case ID: UKSC 2013/0057.

[17] R v Waya [2012] UKSC 51.

[18] Sitting in Judgment, pp. 386-91 and references therein; Final Judgment, p. 99-110.

[19] Sitting in Judgment, ch. 14, on the Court of Appeal. I was privileged to sit with many constitutions of both divisions of the $\mathrm{CA}$, and to observe and report on their deliberations.

[20] In Sitting in Judgment, I described the magistrates' courts and all levels of family court as a law-free zone.

[21] Final Judgment p. 115, fn 197.

[22] Sitting in Judgment, ch. 15.

[23] DPP v Majewski [1976] UKHL 2. In Sitting in Judgment, pp. 386-87, I discussed other notoriously irresponsible and exasperating decisions, decisions such as Hyam v DPP [1974] UKHL 2, on nothing less serious than what constitutes murder, and Boys v Chaplin [1971] AC 356 that, as I said, tortured private international lawyers for years.

\section{[24] [2006] EWCA Civ 1739, at para 63.}

[25] Kay v Lambeth London Borough Council [2006] UKHL 10.

[26] This has been quoted ubiquitously. See Sitting in Judgment, at p. 388. See analysis by Paterson at p. 210.

[27] I examined this in Sitting in Judgment, pp. 386-91.

[28] As well as the references in Sitting in Judgment, see his much-cited 2012 Bailii lecture, delivered as the President of the UKSC and many more speeches, such as "Sausages and the 


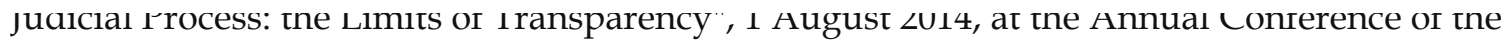
Supreme Court of New South Wales.

[29] She reiterated this in conversation with me in 2014.

[30] 14 February 2014. See also 15 February 2013, reporting that there were 25 single judgments in 2012, of 61 cases.

[31] "Sausages", as above.

[32] $R$ (on the application of Nicklinson and another) $v$ Ministry of Justice [2014] UKSC 38.

[33] Montgomery v Lanarkshire Health Board [2015] UKSC 11.

[34] R (SG) v Secretary of State for Work and Pensions [2015] UKSC 16.

[35] Sitting in Judgment, pp. 377-382; Final Judgment, pp. 73-83.

[36] I am grateful to the Chief Executive for clarifying this.

[37] $R$ (on the application of Eastenders Cash and Carry plc) $v$ The Commissioners for Her Majesty's Revenue and Customs [2014] UKSC 34.

[38] Anson v Commissioners for HMRC, UKSC 2013/0068.

[39] $R$ (on the application of Bourgass) $v$ Secretary of State for Justice, UKSC 2013/0230.

[40] Cramaso LLP v Ogilvie-Grant [2014] UKSC 9. As this was a Scottish civil appeal, there was no permission to appeal stage.

[41] Osborn $v$ The Parole Board [2013] UKSC 61.

[42] International Energy Group v Zurich Insurance PLC, UKSC 2013/0057.

[43] $R$ (on the application of Hemming) $v$ Westminster CC, UKSC 2013/0146.

[44] Sitting in Judgment, p. 353.

[45] On the UKSC website. It is not legally enforceable.

[46] https://www.smith-commission.scot/ 
[47] D. Leask, "MacAskill Threat to end Supreme Court Funding", Herald Scotland, June 1, 2011. 